\title{
Transoral endoscopic thyroidectomy by vestibular approach (TOETVA): initial experience in Brazil.
}

\section{Tireoidectomia endoscópica transoral por acesso vestibular (TOETVA): experiência inicial no Brasil.}

Marco Antonio Scirea Tesseroli ${ }^{1}$; Mauricio Spagnol ${ }^{2}$; Álvaro Sanabria ${ }^{3}$.

\section{A B S T R A C T}

\begin{abstract}
Objective: to present the initial experience in Brazil with transoral endoscopic thyroidectomy by vestibular approach (TOETVA). Methods: prospective study of patients undergoing TOETVA in the Department of Head and Neck Surgery of Hospital Regional do Oeste, Chapecó, Santa Catarina. Patients between 18 and 65 years of age, ASA I and II, with maximum glandular volume of $35 \mathrm{~cm}^{3}$ and nodules up to $4 \mathrm{~cm}$ were candidates for the study. Data of the patients, nodules, surgical time, complications, and length of hospital stay were recorded. Results: nine patients were operated between May 2017 and April 2018. All were women, aged 33-64 years. The size of the nodule ranged from $1 \mathrm{~cm}$ to $4 \mathrm{~cm}$. Two patients had malignant neoplasia and total thyroidectomy was performed in eight cases. Seven patients were hospitalized for only one day. One patient had a minor complication on skin, but there were no lesions of the laryngeal recurrent nerves or definitive hypoparathyroidism. Conclusion: TOETVA is a safe technique for well-selected patients, with favorable conditions and special concern for aesthetic results.
\end{abstract}

Keywords: Thyroidectomy. Mouth. Minimally Invasive Surgical Procedures. Thyroid Neoplasms. Endoscopy.

\section{INTRODUCTION}

7 hyroidectomy is the most commonly performed surgical procedure by head and neck surgeons. The currently widely used surgical technique is similar to that originally described by Kocher, with some minor modifications. Since the advent of endoscopic thyroidectomy, this approach has gained popularity and many variations have emerged, such as cervical endoscopic 1 , axillary², axillo-mammary ${ }^{3,4}$, and retroauricular ${ }^{5}$ accesses, which may or may not have robotic assistance. The main reason for adopting the endoscopic technique is the aesthetic result, which is achieved by reducing the size of the scar, or by placing it in a less visible area. However, all these techniques leave visible scars that are sometimes larger or more prominent than the scars left by traditional procedures.

With the advent of natural orifice transluminal endoscopic surgery (NOTES) ${ }^{6}$, several studies have been published around world 7,8 . In 2016, Anuwong et al. ${ }^{9}$ described the transoral endoscopic thyroidectomy by vestibular approach (TOETVA) ${ }^{10}$, which showed results comparable to the ones of the open thyroidectomy, but with the advantage of not leaving any visible scar. TOETVA is a very new technique performed with conventional laparoscopic instruments. Although widely adopted in Asia, the experience in Europe and America is still small, and there are no reports of this technique in Brazil.

Here we present the initial experience in Brazil, discussing the particularities of this technical innovation and our specific approach, adapted to our health system.

1 - Hospital Regional do Oeste, Department of Head and Neck Surgery, Chapeco, SC, Brazil. 2 - Universidade Comunitária da Região de Chapecó (UNOCHAPECÓ), Surgery, Faculty of Medicine, Chapeco, SC, Brazil. 3 - Universidad de Antioquia, Fundación Colombiana de Cancerología, Clínica Vida, Surgery Department, Medellin, Antioquia, Colombia. 


\section{METHODS}

The candidates for the study were patients between 18 and 65 years of age, ASA I and II, with maximum thyroid gland volume of $35 \mathrm{~cm}^{3}$, and nodules up to $4 \mathrm{~cm}$. Patients with previous cervical surgery, radiotherapy, and hyperthyroidism were excluded. Data on the clinical characteristics of the patients, thyroid volume and nodule size, cytologic and histological diagnoses, surgical time, length of hospital stay, drain use, and complications were recorded. Patients' satisfaction with the procedure was inquired in the second week and in the third month after the procedure, asking whether, hypothetically, they would repeat the same type of procedure or would choose the open technique. All patients received informed consent and the study was approved by the hospital's ethics committee.

\section{Surgical technique}

We followed the technique described by Anuwong et al. ${ }^{10}$ TOETVA is performed with the same videolaparoscopic materials, using a $30^{\circ}$ lens and a vessel sealer or ultrasonic device. To optimize the space in the oral cavity, we used nasotracheal intubation in anesthesia.

A transverse incision of approximately $1.5 \mathrm{~cm}$ is made on the middle portion of the lower lip mucosa anterior to the labial frenulum, deepening through the musculature with monopolar cautery until reaching the lower edge of the mandible. Then, $30 \mathrm{ml}$ of adrenaline-added saline solution $(250 \mathrm{ml} / 1 \mathrm{ml})$ are injected into the subplatysmal space through this incision using a Veress needle. The next step is to perform a blunt dissection employing a rigid cylindrical material - we have used a Hegar cervical dilator - and then a $10 \mathrm{~mm}$ trocar is inserted to accommodate the lens. Two other small incisions $(5 \mathrm{~mm})$ are made laterally on the labial mucosa, near the commissures, almost at the transition between the mucosa and the vermilion of the lip, and adrenaline-added saline solution is then injected through these incisions, and the $5 \mathrm{~mm}$ trocars are introduced. $\mathrm{CO}_{2}$ is injected at a pressure from $6 \mathrm{mmHg}$ to $9 \mathrm{mmHg}$ in a flow rate of $15 \mathrm{~L} / \mathrm{min}$. Dissection follows steps very similar to open surgery, except for the fact that the view is craniocaudal and the infrahyoid muscles are pulled laterally by stitches that are passed through the skin and pulled externally. The caudal limit of dissection is the sternal furcula and the laterals are the anterior borders of the sternocleidomastoid muscle. Another difference is the retrograde dissection of the recurrent laryngeal nerve. For nerve monitoring, the monopolar hook was used disconnected from the electrical source and its posterior extremity was tapped with the needle of the nerve monitor.

Depending on the size of the gland, it may be necessary to fragment it before its removal (through the central incision of the lip). We wore a surgical glove as an endobag, within which the thyroid can be fragmented, if necessary, and then removed, thereby preventing dissemination of thyroid tissue at surgical site.

\section{RESULTS}

Nine patients were operated between May 2017 and April 2018. All were female. The clinical characteristics of the patients, gland size, and surgical data are presented in table 1. There was no conversion to open surgery. In one patient, besides thyroidectomy, a lower parathyroid resection was performed due to an adenoma. 


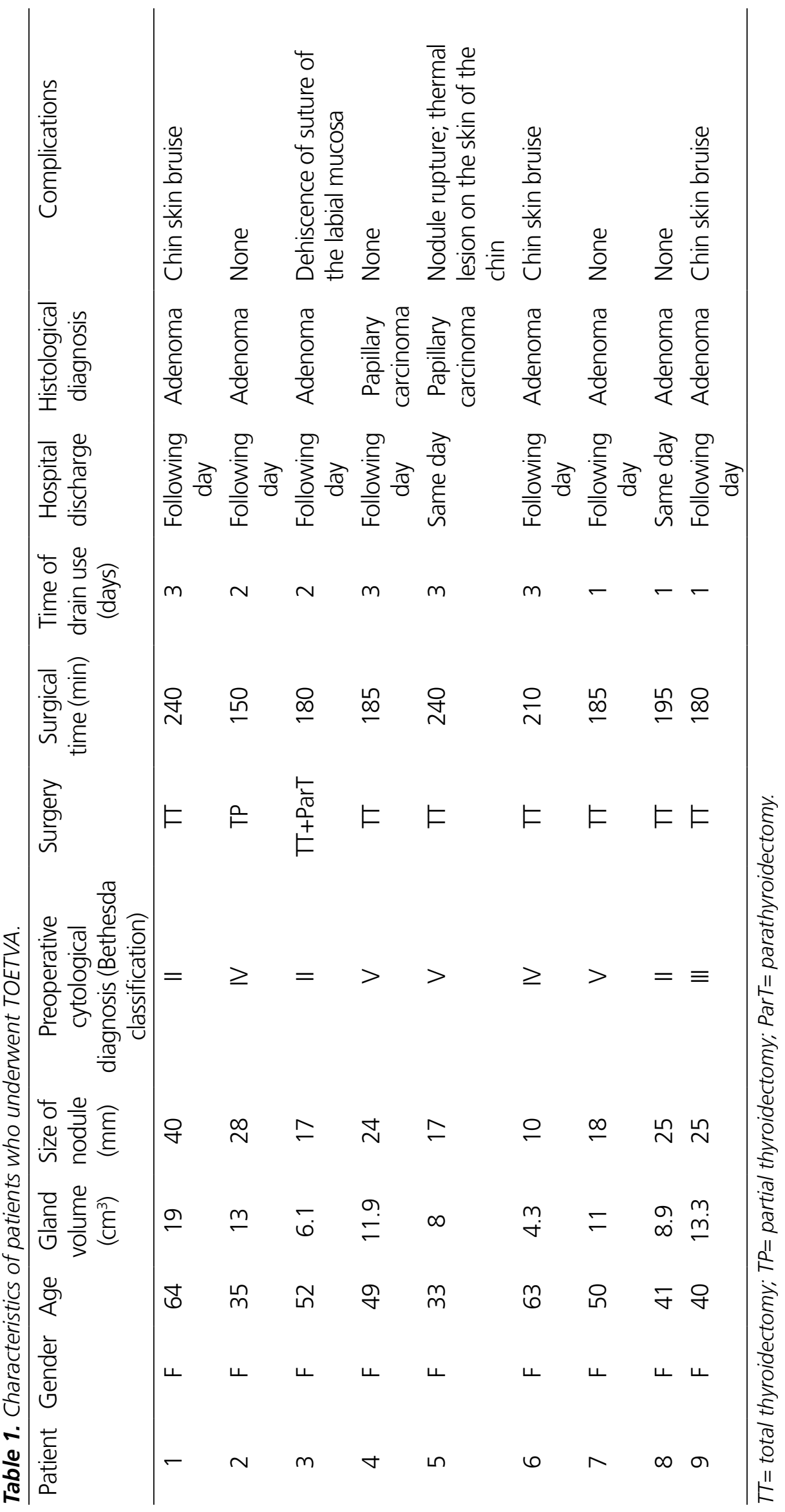


One patient who had a nodule located in the upper pole of the thyroid had rupture of the tumor while seizing the gland for dissection. This patient received $50 \mathrm{mCi}$ of $\mathrm{I}-131$ two months after surgery, with no anomalous uptake in scintigraphy, and undetectable thyroglobulin levels with TSH stimulation. In this same patient, there was a thermal lesion formation on the skin of the chin due to the very superficial dissection during the creation of the tunnel for introducing the $10 \mathrm{~mm}$ trocar. As a consequence, a $4 \times 2 \mathrm{~mm}$ wound was formed and it took about three weeks to resolve it, leaving a very discreet scar.

In the first evaluation, all the patients said they were satisfied with the procedure; however, in the second interview, in the third month after the surgery, one patient, the same who had a thermal skin lesion, showed dissatisfaction, saying that if she had chosen the traditional pathway, her diet would have not been changed in the first postoperative days (liquids and soft foods only).

\section{DISCUSSION}

NOTES technique was described many years ago, initially for cholecystectomy and appendectomy ${ }^{11}$. However, the expansion of this technique to the neck area occurred very slowly due to anatomical issues, which made it impossible to create a good working space, and the lack of instruments for adequate dissection and hemostasis. The emergence of the ultrasonic energy scalpel and optical instruments made possible the completely transoral endoscopic approach.

Although the anterior region of the neck favors the formation of discreet scars, some patients may have unfavorable esthetic results. TOETVA completely eliminates any concern with aesthetic issues and, when compared to other endoscopic techniques, it has some advantages such as: smaller dissection area; access to the two lobes of the gland through the same incision; the surgical equipment is the same used in videolaparoscopic surgery; and the costs are lower when compared with robotic surgery ${ }^{12}$.

Regardless of the pros, there are some limitations in TOETVA. Due to the size of the incision (approximately $1.5 \mathrm{~cm}$ ), sometimes it is necessary to fragment the gland in order to extract it, which can compromise an adequate anatomopathological evaluation, such as margins, capsular invasion, and tumor size.

In patients who have the upper pedicle in a very high position, dissection may be more challenging. Dissection can also be problematic if the tumor is located in the upper pole, since manipulation of this area is essential to expose the recurrent laryngeal nerve in TOETVA, and the seizure of this pole can cause tumor rupture. In men, the more prominent thyroid cartilage may make dissection more difficult. Other issues that should be considered are the costs, which are greater when compared to the open technique, and the surgical time, which is usually higher if compared to the classical approach. As for indications and contraindications, there are different opinions.

Our surgical time was long in all cases, however, not higher than the surgical time published in many other previous publications ${ }^{13}$; and it is expected to decrease with the learning curve, with an improvement after the first twenty cases $^{14}$. We did not observe major complications, such as recurrent laryngeal nerve injury, definitive hypoparathyroidism, infection, and hematoma, nor the need to 
convert to the cervical approach. Many authors have demonstrated safety levels comparable to those of the classical technique $e^{9,10,14}$. The use of drains is still under discussion, but, due to the magnification of the image and the employment of modern vessel sealing instruments, they could be avoided in most cases. Regarding outpatient thyroidectomy, these first cases were carefully observed, but we believe that the indications will be exactly the same as in patients undergoing open thyroidectomy.

An important point is about the risk of infection due to the contact of the saliva with a sterile field. Data from the already published series did not show an increase in the number of surgical site infections. As a general recommendation, a short period of antibiotic prophylaxis is prudent because of the surgery's classification as "potentially contaminated." We have used clindamycin for 24 hours.

One of the major concerns among the authors is related to the risk of mental nerve injury. However, there seems to be no real risk of injury since the most recently described technique is followed ${ }^{15}$. Other questions that need to be answered are whether nerve monitoring provides better results or not, if there is more fibrosis in the surgical bed or greater area of paraesthesia at the site of the patch detachment and trocar passages, and whether there are changes in the function or in the aesthetics of the lip/chin (a case of lip weakness was described $\left.{ }^{16}\right)$. Problems related to skin lesions were also reported ${ }^{17}$.

Finally, cost is an important point to consider. Compared to open surgery, this new approach requires special materials as exposed before. However, the revolution of laparoscopic and robotic surgeries brought to many institutions the technology to make it possible to implement this technique, even in developing countries, overcoming the difficulties of acquiring materials and specific instruments. In addition, nowadays vessel sealers are commonly used in open thyroidectomies, and, so, they could not be considered as an extra cost. The time, which is longer, will be decreased with the learning curve, as has been demonstrated by other endoscopic procedures.

Our initial impression was extremely positive, without major complications and with excellent aesthetic results. It seems to be a useful technique to be offered to well-selected patients (not to all patients), with favorable conditions for the surgery and special concern for the aesthetic result. This is a surgical innovation which will certainly undergo further modifications. More studies should be conducted to answer the topics raised here.

\section{R E S U M O}

Objetivo: apresentar a experiência inicial no Brasil com a tireoidectomia transoral endoscópica por abordagem vestibular (TOETVA). Métodos: estudo prospectivo de pacientes submetidos à TOETVA no Serviço de Cirurgia de Cabeça e Pescoço do Hospital Regional do Oeste, Chapecó, Santa Catarina. Foram candidatos para o estudo os pacientes entre 18 e 65 anos de idade, ASA I e II, com volume glandular de até $35 \mathrm{~cm}^{3} e$ nódulos de até de $4 \mathrm{~cm}$. Dados dos pacientes, dos nódulos, tempo cirúrgico, complicações, e tempo de internação foram registrados. Resultados: nove pacientes foram operados entre maio de 2017 e abril de 2018. Todos eram mulheres, com idades entre 33 e 64 anos. O tamanho do nódulo variou de $1 \mathrm{~cm}$ a $4 \mathrm{~cm}$. Dois pacientes eram portadores de neoplasia maligna e a tireoidectomia total foi feita em oito casos. Sete pacientes tiveram uma internação de apenas um dia. Um paciente sofreu uma complicação menor na pele, mas não ocorreram lesões dos nervos laríngeos recorrentes ou hipoparatireoidismo definitivo. Conclusão: a TOETVA é uma técnica segura para pacientes bem selecionados, com condições favoráveis e com especial preocupação com resultados estéticos.

Descritores: Tireoidectomia. Boca. Procedimentos Cirúrgicos Minimamente Invasivos. Neoplasias da Glândula Tireoide. Endoscopia. 


\section{REFERENCES}

1. Hüscher CS, Chiodini S, Napolitano C, Recher A Endoscopic right thyroid lobectomy. Surg Endosc. 1997;11(8):877.

2. Ikeda Y, Takami H, Sasaki Y, Kan S, Niimi M. Endoscopic neck surgery by the axillary approach. J Am Coll Surg. 2000;191(3):336-40.

3. Shimazu K, Shiba E, Tamaki Y, Takiguchi S, Taniguchi $\mathrm{E}$, Ohashi S, et al. Endoscopic thyroid surgery through the axillo-bilateral-breast approach. Surg Laparosc Endosc Percutan Tech. 2003;13(3):196-201.

4. Choe JH, Kim SW, Chung KW, Park KS, Han W, Noh DY, et al. Endoscopic thyroidectomy using a new bilateral axillo-breast approach. World J Surg. 2007;31(3):601-6.

5. Terris DJ, Singer MC, Seybt MW. Robotic facelift thyroidectomy: II. Clinical feasibility and safety. Laryngoscope. 2011;121(8):1636-41.

6. ASGE; SAGES. ASGE/SAGES Working Group on Natural Orifice Translumenal Endoscopic Surgery White Paper October 2005. Gastrointest Endosc. 2006;63(2):199-203.

7. Witzel K, von Rahden BH, Kaminski C, Stein HJ. Transoral access for endoscopic thyroid resection. Surg Endosc. 2008;22(8):1871-5.

8. Park JO, Kim CS, Song JN, Kim JE, Nam IC, Lee SY, et al. Transoral endoscopic thyroidectomy via the tri-vestibular routes: results of a preclinical cadaver feasibility study. Eur Arch Otorhinolaryngol. 2014;271(12):3269-75.

9. Anuwong A. Transoral Endoscopic Thyroidectomy Vestibular Approach: a series of the first 60 human cases. World J Surg. 2016;40(3):491-7.

10. Anuwong $A$, Sasanakietkul $T$, Jitpratoom $P$, Ketwong K, Kim HY, Dionigi G, et al. Transoral endoscopic thyroidectomy vestibular approach (TOETVA) indications, techniques and results. Surg Endosc. 2018;32(1):456-65.
11. Steinemann DC, Müller PC, Probst $P$, Schwarz AC, Büchler MW, Muller-Stich BP, et al. Meta-analysis of hybrid natural-orifice transluminal endoscopic surgery versus laparoscopic surgery. $\mathrm{Br} J$ Surg. 2017; 104(8):977-89.

12. Pan $J H$, Zhou $H$, Zhao $X X$, Ding $H$, Wei $L$, Qin $L$, et al. Robotic thyroidectomy versus conventional open thyroidectomy for thyroid cancer: a systematic review and meta-analysis. Surg Endosc. 2017;31(10):3985-4001.

13. Shan $L$, Liu J. A systemic review of transoral thyroidectomy. Surg Laparos Endosc Percutan Tech. 2018;28(3):135-8.

14. Russell JO, Clark J, Noureldine SI, Anuwong A, Al Khadem MG, Yub Kim H, et al. Transoral thyroidectomy and parathyroidectomy - A North American series of robotic and endoscopic transoral approaches to the central neck. Oral Oncol. 2017;71:75-80.

15. Kim HY, Chai YJ, Dionigi G, Anuwong A, Richmon JD. Transoral robotic thyroidectomy: lessons learned from an initial consecutive series of 24 patients. Surg Endosc. 2018;32(2):688-94.

16. Richmon JD, Kim HY. Transoral robotic thyroidectomy (TORT): procedures and outcomes. Gland Surg. 2017;6(3):285-9.

17. Bakkar S, Al Hyari M, Naghawi M, Corsini C, Miccoli P. Transoral thyroidectomy: a viable surgical option with unprecedented complications-a case series. J Endocrinol Invest. 2018;41(7):809-13.

Received in: 07/08/2018

Accepted for publication: 09/17/2018

Conflict of interest: none.

Source of funding: none.

\section{Mailing address:}

Marco Antonio Scirea Tesseroli

E-mail: mastesseroli@yahoo.ca alvarosanabria@gmail.com

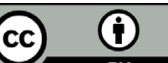

